\title{
Schola Aquitanica (1583): Latin grammar and Renaissance tradition
}

\author{
Melyssa Cardozo Silva dos SANTOS — \\ Universidade Federal Fluminense (UFF)
}

\section{ABSTRACT}

The main objective of this article is to make a discussion on the category of analysis of linguistic thought (SWIGGERS, 2013), having as an object of studies the period of Portuguese Renaissance humanism. To develop this investigation, my theoretical and methodological model is derived from the discipline of Historiography of Linguistics (KOERNER, 1996, BATISTA, 2019). Thus, my specific objective is to analyze the current of thought of Portu-

\section{○}

OPEN ACCESS

EDITED BY

- Gonçalo Fernandes (UTAD)

- Leonardo Ferreira Kaltner (UFF)

- Ronaldo Batista (UPM)

REVIEWED BY

- Marcelo Rocha Gonçalves

(UFMS)

- Jorge Viana de Moraes (USP)

DATES

- Received: 09/15/2021

- Accepted: 09/25/2021

- Published: 12/07/2021

HOW TO CITE

Santos, M. C. S. (2021). Schola Aquitanica (1583): Latin grammar and Renaissance tradition. Revista da Abralin, v. 20, n. 3 , p. 452-463, 2021. guese Renaissance humanism from a specific textual source, the document known as Schola Aquitanica, published in 1583. This document is a school regiment with the didactic orientation of classes and methods to teach humanities, used at the Collège de Guyenne in the 16th century. His editio princeps is entitled Schola Aquitanica (SANTOS, 2021), having as author Élie Vinet (1509-1587), a French humanist. However, in the 16th century edition, there is a more specific internal title: Docendi Ratio in Ludo Burdigalensi (the order of studies at the College of Bordeaux), which is also known in French as Le Programme d'Études du Collège de Guyenne (the program of studies at the College of Guyenne).

\section{RESUMO}

O objetivo geral deste artigo é fazer uma discussão sobre a categoria de análise do pensamento linguístico (SWIGGERS, 2013), tendo como objeto de estudos o período do humanismo renascentista português. Para desenvolver esta investigação, meu modelo teórico-metodológico é derivado da disciplina de Historiografia da Linguística (KOERNER, 1996, BATISTA, 2019). Assim, o meu objetivo específico é analisar a corrente de pensamento do humanismo renscentista português a partir de uma fonte textual específica, o documento conhecido como Schola Aquitanica, publicado em 


\section{REVISTA DA ABRALIN}

1583. Este documento é um regimento escolar com a orientação didática de aulas e métodos, para o ensino de humanidades utilizado no Collège de Guyenne no século XVI. Sua editio princeps intitula-se Schola Aquitanica (SANTOS, 2021), tendo como autor Élie Vinet (1509-1587), um humanista francês. No entanto, na edição do século XVI, há um título interno mais específico: Docendi Ratio in Ludo Burdigalensi (a ordem de estudos no Colégio de Bordeaux), que também é conhecido em francês como Le Programme d'Études du Collège de Guyenne (Programa de estudos do Colégio de Guiena).

\section{KEYWORDS}

Missionary Linguistics. Linguistic Historiography. Grammaticography. Renaissance humanism.

\section{PALAVRAS-CHAVE}

Linguística Missionária. Historiografia da Linguística. Gramaticografia. Monumenta Anchietana. Humanismo Renascentista.

\section{Introduction}

The general objective of the article is a debate on linguistic thought (SWIGGERS, 2013) in the period of Portuguese Renaissance humanism. To establish this debate, the theoretical and methodological model of the discipline of Historiography of Linguistics is used (KOERNER, 1996, BATISTA, 2019). Thus, the specific objective of the article is to analyze the current of thought of Portuguese Renaissance humanism from a specific textual source, the document known as Schola Aquitanica, published in 1583.

The document is a school regiment with the didactic orientation of classes and methods to teach humanities, and this regiment was in use at the Collège de Guyenne in the 16th century. His editio princeps is entitled Schola Aquitanica (SANTOS, 2021), having as author Élie Vinet (1509-1587), a French humanist. However, in the 16th century edition, there is a more specific internal title: Docendi Ratio in Ludo Burdigalensi (the order of studies at the College of Bordeaux), which is also known in French as Le Programme d'Études du Collège de Guyenne (the program of studies at the College of Guyenne).

Élie Vinet describes in the work the school management of the College of Guyenne at the time when the Portuguese humanist André de Gouveia (1497-1548) was the institution's director, developing a program of studies aimed at Renaissance humanistic education (MIRANDA, 2011). The editio 


\title{
REVISTA DA ABRALIN
}

princeps edited and published by Élie Vinet, in 1583, is available on the $\mathrm{BnF}^{1}$. Later, in 1886, a bilingual edition, in Latin and French, with commentaries, was published by theologian Louis Massabieau (1840-1904), who wrote about the context of the document and its importance to understand the reform of education on 16th century by protestants and jesuits:

\begin{abstract}
Tout le monde sait que le programme du collège de Guyenne fait partie d'un des plus brillants épisodes du développement des études en France au XVIe siècle. Par son étendue, par les détails curieux dont il est plein, par la rareté de ce genre de documents avant les réformes des protestants et des jésuites, par son caractere de transition entre ces réformes et l'usage de l'Université de Paris, ce programme est certainement une des pièces les plus importantes pour l'histoire de l'instruction publique dans notre pays.(MASSEBIEAU, 1886, p.V).
\end{abstract}

The Schola Aquitanica consists of a syllabus for the teaching of the humanities. Above all disciplines is focused on the teaching of Latinities (latinitas), that is, the teaching of Latin grammar, in the context of the 16th century. The humanistic tradition, which is the context of Schola Aquitanica, begun after the medieval age preserving, however, the teaching of Latin language (COLOMBAT et al, 2017). The document was written in Latin language by the French humanist Élie Vinet, but records the teaching activities of a group of humanists at the College of Guiena, in France, under the administration of the Portuguese humanist André de Gouveia (1497-1548), so represents the linguistic thought of an intellectual circle of humanists. Although it was written by a French humanist, its tradition goes back to Portuguese Renaissance humanism, as described on another studies (KALTNER, 2019a; KALTNER, 2019b; KALTNER, 2020a; 2020b; 2020c; 2020d; KALTNER, SANTOS, 2020e; KALTNER, 2020f).

The humanistic education of the time was linked to the teaching of Latin grammar together with the use of several didactic works and the reading of classical authors of Latin literature, this pattern of educaction was common to missionary of religious orders and humanists in the 16th century (ZWARTJES, 2011). The syllabus of the College of Guiena is derived from a humanistic tradition, that started with Erasmus of Rotterdam (1466-1539), and its relations with European Renaissance humanism is evident.

The system of the teaching at the College of Guyena followed the serial format, being divided into ten levels, or annual series. Vinet comments that the series could be divided into up to twelve, if it were necessary to repeat any of the series. These college levels were also called grammar classes. The grammar classes were intended to teach Latin grammar in conjunction with the French language. The first level began with grammatical elements, based on the work of some prestigious grammarian or used in other schools at that time. The grammar of Jan Van Spauter (ca. 1480-1520), or Despauterius, the Commentarii Grammatici (SANTOS, 2021) was recommended in the document.

In addition to the ten classes of Latin grammar, there were also philosophy classes in Greek language and public lectures. The grammar classes were organized in a descending way, with the tenth class corresponding to the elementary level and the first class the most advanced level. The

\footnotetext{
${ }^{1}$ Bibliothèque nationale de France $(\mathrm{BnF})$.
} 


\section{REVISTA DA ABRALIN}

tenth class consisted of children up to seven years old. These students, called alphabetists (alphabetarii), were sent to the school by their guardians not only to become literate, but also to start their studies in the Latin language.

\section{The ten classes of Latin grammar}

In the first class, the tenth, two small books were used as teaching material: the Alphabetum and the Libellus Puerulorum. The first booklet introduces the alphabet and some prayers, from which lessons are taken in class to students. The second booklet addresses some elements of grammar as an introduction to Latin grammar studies:

Decima classis in Schola Aquitanica, est eorum, quos a duabus litteris Graecis Alpha et Beta, Alphabetarios:
vel a quattuor Latinis ABCD, Abecedarios vulgo vocitamus. Pueruli sunt, et minores etiam septem annis pue-
ruli, ut Fabio placuit: qui a parentibus, et propinquis in Ludum, prima litterarum Latinarum; ut Latino sermoni
cognoscendo haec schola in primis destinata est, elementa cognituri ex his duobus libellis, mittuntur: quorum
alter et prior, unde nomen habent, Alphabetum inscribitur: qui libellus eorum causa impressus, nullis sylla-
barum compendiis, viginti trium litterarum contextum et formas, Orationem Dominicam, septem psalmos,
et quaedam alia exhibet. Alter vero, qui ut parvus et parvorum est, ita Libellus Puerulorum quoque dicitur et
qui continet primas nominum et verborum declinationes. Ita mature iis instituuntur, quae prima sunt in La-
tina arte Grammatica (SANTOS, 2021, p. 52).

The tenth class of the Aquitaine College was made up of boys of literacy age, so the children studied with others of the same age. They were literate at the age recommended by Quintilianus, whose works influenced humanistic thought. They were, in general, children up to the age of seven, sent to schools by their parents and tutors, to learn to read and write in French and Latin. The alphabet, the syllabic system, dictations and copying texts were his main tasks. Humanists prized early childhood education.

The two teaching materials used with children of this age were very specific and simple. The Alphabetum was just a literacy booklet with the geometric figure of the letters, and the Libellus Puerulorum, the children's booklet, was a compendium of tables with Latin nominal declension and verbal conjugation, that should be memorized. The first complete texts to be learned were Christian prayers and psalm reading.

There were some desks in the class for students to attend classes and practice their activities, so they were arranged in five rows. Each child's position on the desks ranked their level of

\footnotetext{
2 Translation (SANTOS, 2021): The tenth class of the College of Aquitaine is composed of the so-called alphabetarians, with two Greek letters alpha and beta, or generally abecedarians, with the four Latin letters A, B, C, D. They are little children, under seven years old, as Quintilian says. Their parents and tutors send them to the school to learn the first elements of Latin letters, as the main objective of this establishment is knowledge of the Latin language. We teach these elements through two booklets. The title of the first is the Alphabetum (Alphabet), from which they take their own names. The form is addressed to them, without abbreviations, it contains the sequence and figures of twenty-three letters, the Oratio dominica (Sunday prayer), the seven penitential Psalms etc.
} 


\section{REVISTA DA ABRALIN}

development in the class. Generally, the students in the first row were the most educated and well prepared to change classes, whereas the students in the last row should have better results in activities and assessments (SANTOS, 2021).

In the ninth grade, children were supposed to learn to read and write Latin and French quickly. The elements learned in the tenth grade were exercised. The main knowledge to be worked on were the inflections of nouns and verbs at this class. The parts of the clause (partes orationis) were also studied, little by little the elements of grammar were introduced, with the syntax of simple sentences. For this purpose, the humanists used the work Distichs of Cato, or the work of Simon Millanges, the Latin Cato with a French translation and the Erasmus' work Sayings of the Seven Sages (Dicta Septem Sapientium). From Catão's couplets, they studied inflections and elements of grammar, especially syntax of simple sentences:

Hujus autem classis quum hoc sit officium, ut pueri bene et velociter Latina Gallicaque legere et scribere perdiscant: deinde ut nomina et verba declinare in primis sciant, ac prima Grammatices elementa sensim cognoscere incipiant, in quam rem prostant a Simone Millangio impressi Catonis Latine et Gallice interpretati, Declinationum et Rudimentorum Grammatices, libri, hora octava, quum primum ingressus est praeceptor, primi ordinis pueri duas aut tres sententias recitant ex Catonis praefatione, aut ex dictis Sapientum, quae Catoni subjecta sunt, ut praeceptori visum fuerit (SANTOS, 2021, p. 54) ${ }^{3}$.

The texts, which were constituted as simple sentences written in Latin language, should be memorized by the students. Gradually the themes of Despauterius' Rudimenta were introduced, like the identification of the eight parts of the clause, and their forms: nomen, pronomen, verbum, adverbium, participium, coniunctio, praepositio and interiectio.

It was common practice to recite the elements (Rudimenta) of Latin grammar, each row having its own distinct lesson. The works were copied by hand, as a way to favor the memorization process. There was the division of letters and syllables in the texts at this level. It was common, also, the exercise of inflection of names and verbs, in Latin, with all the declensions and all the tenses and verb modes.

Already in the eighth grade, the third year of studies, the books were different. In addition to Despauterius' grammar, the books for the eighth grade were a selection of Cicero's letters, Terentius' comedies, and the colloquia of the French humanist Marturin Cordier (1479-1574). These three works were divided into daily lessons to be memorized. The dialogues should be staged, in groups, as well as the colloquia. There was, from then on, a focus on the use of Latin as an active language for speech. The children used the books to study and, at the same time, a blank notebook for copying:

\footnotetext{
${ }^{3}$ Translation (SANTOS, 2021): In this class, children should learn to read and write Latin and French very quickly, and, in addition, know the inflections of nouns and verbs well, and gradually begin to learn the first elements of Grammar. For this purpose, we use the work of Simon Millanges, the Latin Cato with French translation, as well as inflections and grammar elements. At eight o'clock, at the time of the master's entrance, the students in the first row read aloud two or three sentences from Cato's preface, or the Sayings of the Seven Sages (Dicta Sapientium) which are the sequel to Cato, selected by the master.
} 


\title{
REVISTA DA ABRALIN
}

\begin{abstract}
Octavo ordini, sui sunt libri destinati, unus ex selectis epistolis Ciceronis: alter ex aliquot scenis Terentii: tertius ex Colloquiis Maturini Corderii, cuncti in lectiones distributi, singulis diebus ediscendas pueris. Primum itaque horum librorum sibi emunt pueri, quemcunque praeceptor est praelecturus, et simul librum purum. Ex illis domi perpetuo residentibus, in hoc pueri lectionem describunt, quem secum in Ludum ferunt, cum iisdem declinationibus et Rudimentis Grammatices. In auditorio, ubi certas sedes semper habent pueri, primus contextum, quem descriptum domo attulit, legit: secundus expositionem, tertius orationis partes, quartus contextum rursus, et sic deinceps usque ad ultimum. Deinde ad singula contextus verba devenitur. Primus verbum primae orationis enuntiat. Id conjugant pueri, unus Indicativi praesens, alius praeteritum imperfectum: ac ita deinceps alii modi et tempora subduntur (SANTOS, 2021, p. 56) ${ }^{4}$.
\end{abstract}

In the seventh grade, the fourth year of studies in Latin grammar, there was a deepening of the study of Cicero's work. The study of Cicero's work characterized Renaissance humanistic education since the 15th century. Thus, the main works studied by the children were the family letters (Epistolae famliares) of Cicero, which made up the first texts by classical Latin authors to be known by humanists. The teaching process was done with a first lecture, that is, an explanation of a Cicero's letter in French, followed by reading the text in the Latin original, memorizing the easiest letters, until emulation.

The humanist preceptor gives students the explanation of the content entirely in French, unless he needs to explain something in Latin, or make some modification to the sentence for the convenience of the explanation. The objective of this level of teaching in Latin grammar is textual interpretation. In this respect, the content of Cicero's family letters is studied before the Latin text. The preceptor gives the explanation word for word as much as possible, inflecting it word for word if necessary to teach the declensions of Latin grammar.

If in this way the explanation is still too complex for children to understand, he replaces the French text with one more easy in keeping with the essence of the French language. The main objective was to teach textual interpretation:

Septimanis praelegitur liber aliquis ex facilioribus Epistolarum Familiarium Ciceronis. Hunc asservant
domi emendate impressum: ex quo sua ipsi manu transcribunt in librum purum, quem secum in Ludum
cum declinationibus et Rudimentis ferunt, quantum eo die praelegi convenit, tres nimirum aut quat-
tuor versus formae octavae. Inter eos versus intervalla obesrvant semipollicaria minimum: ut ea expo-
sitionem, quam puer excipere debet, capere late possint. Praeceptor ex suo libro eosdem praelectionis
versus recitat, distinguit orationes, monet, si quo in verbo orthographiam fuisse neglectam suspicetur:
et siquod forte nomen minuscula littera ait scriptum, quod, majuscula debeat, vel contra. Deinde ex-
plicationem aggreditur: quae tota Gallice fit, nisi forte aliquid Latini subaudiendum sit, aut

\footnotetext{
4 Translation (SANTOS, 2021): The books for the eighth grade are a selection of Cicero's letters, Terencius' scenes and Marturin Cordier's colloquia. These three works are divided into everyday lessons to be learned by heart. The children buy, first of all, the book that the teacher must explain, and at the same time a blank notebook. They always bring their books from their homes and copy the lesson in the notebook they bring to school, with the inflections and grammar elements that they had already copied previously. In the auditorium, where the children always have their assigned places, the first reads the text he copied at home, the second the explanation, the third the parts of the speech, the fourth rereads the text, and so on until the last. Afterwards, we pass the evaluation of the words in the text. The first says the verb of the first sentence. The children then conjugate one in the present indicative, the other in the imperfect one, and so on for the other modes and tenses.
} 


\section{REVISTA DA ABRALIN}

commutandum quippiam, rei commodius explicandae gratia: eaque per singula verba procedit, quantam fieri potest. Quae si sic inepta est, ut vix intelligi possit a pueris, subjicitur alia Gallico Idiomati convenientior (SANTOS, 2021, p. 57) ${ }^{5}$.

In the sixth grade, which is equivalent to the fifth year of studying Latin grammar, there was a continuation of the study of Cicero's family letters, at the College of Guyenna. The texts were explained in French, but studied in Latin, word by word and sentence by sentence, always with memorization activities. After studying the elements of Despauterius' grammar (Rudimenta), the reading of the first part (Prima pars) of the grammar began. Some specific topics of Latin grammar were studied, such as genders, declensions, past tenses and supines, as well as the specific syntax of the cases. The grammar was written in Latin language.

The main author studied was still Cicero, however, after the sixth grammar class, the study of other classical authors would come. The first part of Despauterius' grammar brought the irregularities of the Latin language grammar and the specific language uses of classical authors, preparing students to read other Roman authors:

In hac classe enarratur etiam Gallice aliquis liber earundem Ciceronis Epistolarum: et praelecta mane,
pueri reddunt memoriter vesperi: aut postridie mane, si vesperi praelecta fuerint. Hora duodecima,
Despauterii Genera, Declinationes, Praeterita et Supina, et praeterea Syntaxis, quantum vacabit.
Repetuntur vero, et fiunt reliqua omnia sicut in septimo ordine monstratum est (SANTOS, 2021, p. 58) ${ }^{6}$.

In fifth grade, which was equivalent to the sixth year of studies in Latin grammar, there was the study of yet another of the books of Cicero's family epistles and the study of another book of the grammar written by Despauterius. Through the grammar of Despauterius, the humanists explained the genders and declensions of the names, with the heteroclites, then the past tenses and the supines of the verbs. Syntax was explained by the grammar also, and finally the book dedicated to the art of versification, with the study of figures of speech.

\footnotetext{
${ }^{5}$ Translation (SANTOS, 2021): In the seventh, we explain one of the easiest books in Cicero's family epistles (Family Epistles). The print must be correct. Students keep the printed book in their homes. They copy, with their own hands, in a blank notebook, which they bring to the school, with the inflections and the elements, the passage of the day that will be explained, that is, three or four lines of a page in eighth format (in-octavo). Between each line, they leave an interval of at least half an inch, so that the explanation, which must be written down by the child, remains comfortable in reading. The teacher reads aloud, in his book, the same lines of the lesson: he distinguishes the sentences. If the spelling of a word seems incorrect to him he makes the observation, likewise, he points out whether any name is written with a lowercase instead of an uppercase or vice versa. Then he starts the explanation. The master gives students the explanation of the content entirely in French, or in the vernacular, unless he needs to hear something in Latin, or make some modification to the sentence for the convenience of the explanation. He gives the explanation word for word as much as possible. If in this way the explanation is still too complex for children to understand, he replaces the text with one more in keeping with the essence of the French, or vernacular, language.

${ }^{6}$ Translation (SANTOS, 2021): In this class, we also explain in French some of Cicero's epistles. The morning lesson text is recited by students in the afternoon, or the next morning if the explanation of the text took place the previous afternoon. At noon, with the grammar of Despauterius, we study the genders, the declensions, the past tenses and the supines, and beyond that the syntax, as much as time allows. We go over and do the remaining exercises like in seventh grade.
} 


\title{
REVISTA DA ABRALIN
}

Grammatical content ended at this level of education, but it would still be repeated on other levels. Soon, the practice of Latin as an active language began to increase. There was the reading of dramatic texts, such as the comedies by Terentius. Ovid also began to be studied, from his epistles, which were emulated in linguistic exercises:

\begin{abstract}
In quincta classe, hora octava, Ciceronis Epistolarum Familiarium liber aliquis Gallice exponitur. Meridiana, Despauterii Genera et Declinationes nominum cum Heteroclitis, Praeterita et Supina verborum, et Syntaxis, ac tandem ars Versificatoria cum Figuris. Tertia, Terentii comoediarum aliqua, et sub anni finem aliqua Ovidii epistola. In repetendis autem postridie lectionibus, et de thematibus, omnia fiunt, sicut dictum fuit de sexto ordine et septimo (SANTOS, 2021, p. 58-59)?
\end{abstract}

In the fourth grade, which was equivalent to the seventh year of study, the humanists taught their students the Latin of Cicero, by reading another book from the family letters, or from letters to Atticus. There was a review of grammatical contents, such as genders, declensions and heroclites, based on Despauterius' grammar. At this stage of learning, a speech by Cicero was studied with a compendium of rhetoric. Despauterius' grammar was still read, in the final books on syntax, the art of versification, and figures.

The humanists continued to teach latin as an active language by the study of Terentius' comedies and Ovid's works, especially the Tristes (Tristia) or the Ponticas (Epistulae ex Ponto). The grammar was recited and analyzed, with more extensive readings. There was the exercise of producing short poetic texts, by emulating the studied authors:

In quarto ordine hora octava, anni initio, praelegitur liber aliquis Familiarium, aut ad Atticum epistolarum: simulque Despauterii Genera, Declinationes, ac Heteroclita percurruntur. Quibus absolutis oratio aliqua Ciceronis ex familiaribus substituitur, et compendium aliquod Rhetorices ex facilioribus. Meridie vero Syntaxis, ars Versificatoria, et Figurae ejusdem Despauterii. Hora tertia, una ex Terentii fabulis explicatur: qua absoluta, progressus est ad Ovidium de Tristibus aut de Ponto. Repetuntur vero postridie omnia quae fuerunt praelecta pridie, et ad Grammatica: regulas exiguutur, ubi memoriter prius reddita fuerint. Themata vero frequentiora et longiora proponuntur, quam in classibus inferioribus: simul nonnulla versuum argumenta, sed haec brevia et facilia (SANTOS, 2021, p. 59) ${ }^{8}$.

\footnotetext{
${ }^{7}$ Translation (SANTOS, 2021): In fifth class, at eight o'clock, we explained in French a book of Cicero's family epistles. At noon, with Despauterius's grammar, we explain the genres and declinations of the names, with the heteroclites, then the past tenses and the supines of the verbs and the syntax, finally, the art of versification, as well as the figures. At three o'clock we read a comedy by Terencio, and, towards the end of the year, an epistle by Ovid. As for the lessons to be passed on the next day and the themes, everything is done as in the sixth and seventh grades.

${ }^{8}$ Translation (SANTOS, 2021): In the fourth class, at eight o'clock at the beginning of the year, we explain a book from the family epistles of Cicero or the family epistles from Cicero to Atticus; at the same time, we quickly review the genres, the declinations and the heroclites, based on the grammar of Despauterius. That done, we selected one of Cicero's speeches among the simplest and some compendium of rhetoric that is among the easiest. At noon, we teach the syntax, the art of versification and the figures of the same Despautery. At three o'clock we explain a comedy by Terentius: after it's over, we move on to the Tristes (Tristia) or the Ponticas (Epistulae ex Ponto) by Ovid. We repeat the next day in the morning everything that was explained the day before, and then analyze the grammar rules after reciting them. The themes are more numerous and longer than the lower classes: we also dictate some matter of Latin verse, but short and easy.
} 


\section{REVISTA DA ABRALIN}

In the third grade, equivalent to the eighth year of studies, the humanists explained, in French, another book from the family epistles and epistles to Atticus, Brutus and Quintus of Cicero to their students. In addition to Cicero's epistles, manuals of rhetoric were also studied, with a continuity of readings from the previous level. Despauterius' grammar was studied continously, in the same sequence as before, with the study of syntax and the art of versification, starting from a revision of the book of figures.

There was a continuation also of reading Terentius' comedies and reading Ovid's work. At this level, a book of the Fasti or the Metamorphoses was read. There was the study of the works of Cicero, Ovid and the grammar of Despauterius, in order to memorize the grammatical rules of Latin:

Tertianis hora octava exponitur Ciceronis Epistolarum liber Familiarium, aut ad Atticum Brutumve, aut ad Quinctum fratrem, usque ad Calendas Januarias, idque Gallice. Post quod tempus, Ciceronis oratio aliqua ex facilioribus praelegitur, atque simul praecepta Rhetorica ex aliquo scriptore optimo. Hora Meridiana explicatur Syntaxis, ars Versificatoria, liber de Figuris ex Despauterio, quibus absolutis substituitur Terentii fabula. Hora tertia praelegitur Ovidii Fastorum aut Metamorphoseon liber aliquis. Postridie vero memoriter redditur pridiana Ciceronis, Ovidii Despauteriique lectio: et in Ciceroniana Ovidianaque repetenda Grammatices praecepta diligenter inculcantur. Themata autem Gallica non minus frequentia hic sunt, quam in quarto ordine, sed ampliora aliquanto: quibus accedunt argumenta ad versus scribendos frequentiora ${ }^{9}$.

In the second class, which was equivalent to the ninth year of studies, the humanists ended the teaching of Cicero's letters and began the systematic study of the speeches of the Roman orator. Rhetoric was the central theme, with the study of a speech by Cicero and the partitiones. The genre of rhetoric texts was the specific theme, after the epistles.

The history of Rome began to be explained, and the grammatical content derived from the rereading and deepening of themes by the grammar of Despauterius. Virgil began to be studied at this level, in which Ovid's Metamorphoses were also read. Another author studied was Lucan and his work, Farsalia. There was an introduction to the epic genre.

The humanists carried out textual and poetic production activities, such as composing small epigrams in Latin. There was also the incentive for private and public declamations, a very common task in the 16th century academic institutions:

In secunda classe mane orationum Ciceronis aliqua praelegitur, et Partitiones, aut aliquid tale Rhetoricum. Hora Meridiana traditur historia, post Despauterii Versificatoriam et Figuras repetitas. Tertia vero aliquid Virgilii, aut Metamorphoseon Ovidii inter caetera, aut Pharsaliae Lucani. Quincta vero proponitur epigrammatis argumentum, ante dimissionem magistro reddendi. Repetuntur autem hic praelecta ac ediscuntur non segnius, atque in tertio ordine fit. Declamationibusque assuefiunt paulatim secundani tam

\footnotetext{
${ }^{9}$ Translation (SANTOS, 2021): In the third, at eight o'clock, we explain the family epistles of Cicero or the epistles to Atticus or Brutus or his brother Quintus, until January 1st, and that in French. Then an easy speech by Cicero, and at the same time the rhetoric of some good author. At noon, syntax, the art of versification, based on the book of 'figures' in Despauterius: done, a comedy by Terentius. At three o'clock, a book of the Fasti or the Metamorphoses of Ovid. The next morning we recite Cicero, Ovid and Despauterius; by repeating Cicero and Ovid, the master seriously inculcates the rules of grammar. The French themes are here also numerous as in the fourth class, but a little longer: we often add a little more of the material on Latin verses.
} 


\title{
REVISTA DA ABRALIN
}

privatis quam publicis: quum interim non cessent Gallica themata, argumentaque orationurn et carminum, sicut in Tertio Quartoque ordine fieri coeptum (SANTOS, 2021, p. 60) ${ }^{10}$.

In the first grade, which was equivalent to the tenth year of studies, Latin grammar gives way to rhetoric. Cicero and Quintilian were studied. The humanists taught the history of Rome, according to Titus Livius, Justinus, Seneca, Flavius, Eutropius, Pomponius Mela, among others. Poets were studied, such as Virgil, Lucan, Persius, Juvenalis, Horace and Ovid. Poetic composition was practiced, with the entire educational program in teaching Latinities completed. There was, later, the course of Philosophy in two years, after the first class, with the teaching of Aristotle:

\begin{abstract}
Etsi haec, et quae praecedunt, Grammaticorum classes sunt omnes, tamen in quattuor superioribus, et praecipue in hac prima, tractatur Rhetorica. Sic veteres Grammaticos in Latio etiam factitasse Suetonius auctor est. Mane ergo hora octava praecepta oratoria ex Cicerone vel Quinctiliano traduntur. Nona, Ciceronis aliquid, maxime orationes, quo praecepta illa Ciceronis lectione confirmentur, et in usum scribendo declamandoque transferantur. Hora Heridiana, traditur historia ex Livio, Justino, Seneca, Eutropio, Mela, aut simili. Hora tertia, Poetice, ex Virgilio maxime, et Lucano, et Persio: tum ex Juvenale, Horatio et Ovidio: siquid casti habent (SANTOS, 2021, p. 60) ${ }^{11}$.
\end{abstract}

\section{Conclusion}

The Schola Aquitanica (VINET, 1583) was not just a descriptive document of the activities of the College of Guyenne limited to French, as the study plan influenced other humanistic schools. André de Gouveia was also the founder of the Royal College of Arts of Coimbra in 1548. The first statutes of the Portuguese humanistic college are very close to the teaching model of Guyenne.

There are two Portuguese documents that corroborate the influence of the Schola Aquitanica model of humanistic education in Portugal, in the 16th century. The Regiment of the Royal College of Arts, of November 16, 1547, and the Statuta, of April 26, 1548, are the two regulations that were the basis of the first Portuguese humanistic college. The documents present the rules of teaching and also the

\footnotetext{
${ }^{10}$ Translation (SANTOS, 2021): In the second class, in the morning, we explain a speech by Cicero and the 'divisions' (partitiones) or any other work of the same genre on rhetoric. At noon, we teach history after repeating the art of versification and the figures of Despauterius. At three o'clock, something by Virgil, or any part of Ovid's Metamorphoses and other works by this poet, or Lucan's Pharsalia. At five o'clock, the master presents the theme to compose a short piece of verse (epigramma) that students must hand over to him before leaving class. In the second grade, the texts explained and learned by heart are repeated as carefully as in the third. In this class, we gradually picked up the custom of both private and public declamations, without interrupting the learning of argumentation in French, so that the subjects of discourse and versification have already started to present in the third and fourth classes.

${ }^{11}$ Translation (SANTOS, 2021): Although this class and the previous ones are all grammar classes, however, in the four upper classes, and especially in the first one, we deal with rhetoric. Such was the use of ancient Latin grammarians in the testimony of Suetonius. Then, in the morning, at eight o'clock, the precepts of the oratory art according to Cicero or Quintilian are taught. At nine o'clock, we started with a work by Cicero, preferably one of his speeches, to confirm his precepts, we continued reading Cicero and putting his precepts into practice through written activities and declamations. At noon, we teach history according to Titus-Livy, Justin, Seneca, Flavius, Eutropius, Pomponius Mela, or any similar author. At three o'clock, we read the poetics, above all according to Vergil, Lucan and Persius, without forgetting Juvenalis, Horace and Ovíd, but in places where they respect customs.
} 


\section{REVISTA DA ABRALIN}

organization of the classes, with the subjects that should be taught in the classroom. These documents show to modern readers characteristics that are very close to the regulations of the College of Guyenne. In Portugal, this teaching model was recognized by the name of modus parisiensis.

S. José de Anchieta, SJ (1534-1597) studied as a teenager at the Royal College of Arts of Coimbra, between 1548 and 1551, having as preceptor the humanist Diogo de Teive. The humanist Diogo de Teive was a professor at Colllege of Guyenne at the time of André de Gouveia, having participated in the humanistic education process of the institution. In this sense, Schola Aquitanica probably influenced Anchieta's education, before he came to Brazil in Sixteenth century.

\section{REFERENCES}

BATISTA, Ronaldo de Oliveira. Historiografia da Linguística. São Paulo: Contexto, 2019.

COLOMBAT, Bernard; FOURNIER, Jean-Marie; PUECH, Christian. Uma história das ideias linguísticas. Tradução Jacqueline Léon, Marli Quadros Leite. São Paulo: Contexto, 2017.

KALTNER, Leonardo Ferreira. As ideias linguísticas no discurso De Liberalium Artium Studiis (1548). Confluência, Rio de Janeiro, n. 56, p.197 - 217, 2019a.

KALTNER, Leonardo Ferreira. O Brasil quinhentista e a Historiografia Linguística: interfaces. Cadernos do CNLF (Cifefil), Rio de Janeiro, n. 23, p.424-439, 2019b.

KALTNER, Leonardo Ferreira. Monumenta Anchietana à luz da Historiografia Linguística: o trabalho filológico de Pe. Armando Cardoso, SJ (1906-2002). Cadernos de Linguística da Abralin, ano 1, n.1, p.01-15, 2020a.

KALTNER, Leonardo Ferreira. O pensamento linguístico de Anchieta e de Carl von Martius: estudos historiográficos. Ponta Grossa: Atena Editora, 2020b.

KALTNER, Leonardo Ferreira. Por uma edição crítica da gramática de Anchieta (1595). Revista Philologus, Rio de Janeiro, ano 26, n. 76, v. 2., p.717 - 731, set./dez. 2020c.

KALTNER, Leonardo Ferreira. Regna Brasillica: contextualização da Arte de gramática da língua mais usada na costa do Brasil (1595). Revista da Abralin, n.19, p.1 - 25, 2020 d.

KALTNER, Leonardo Ferreira; SANTOS, M. C. S. Schola Aquitanica e a gramática de Despauterius: intertextualidades. Revista Philologus, Rio de Janeiro, n. 76, v. 2, p.750-759, 2020e.

KALTNER, Leonardo Ferreira. The Grammar Corpus in the Horizon of Retrospection of S. José de Anchieta, SJ (1534-1597). Global Journal of Human-social Science: G Linguistics E Education, Framingham, n. 20, p.37-44, 2020f.

KALTNER, L. F.; SANTOS, M. C. S. DOS. A Decima Classis do Schola Aquitanica (1583): educação humanística renascentista à luz da Linguística Missionária. Cadernos de Linguística, v. 2, n. 4, p. e501, 11 set. 2021.

KOERNER, Konrad. Questões que persistem em Historiografia da Linguística. Revista da Anpoll, n. 2, p. 45-70, 1996. 


\section{REVISTA DA ABRALIN}

MIRANDA, Margarida. As artes do Real Colégio das Artes. Entre sua matriz e outra. Biblos, Coimbra, n. 9, 11-31, 2011

SANTOS, Melyssa C. S. dos. Schola Aquitanica (1583): edição bilingue com comentários à luz da Historiografia Linguística. 107f. Dissertação (Mestrado em Estudos de Linguagem) - Instituto de Letras, Programa de Pósgraduação em Estudos de Linguagem. Universidade Federal Fluminense, Niterói, 2021.

SWIGGERS, Pierre. A historiografia da linguística: objeto, objetivos, organização. Confluência, Rio de Janeiro, n. 44-45, p. 39-59, 2013.

VINET, Élie. Schola Aquitanica. Bordeaux: Simon Millanges, 1583.

ZWARTJES, Otto. Portuguese missionary grammars in Asia, Africa and Brazil, 1550-1800. Amsterdam: John Benjamins, 2011. 